\title{
Geological Field Mapping and Heavy Metals Assessment in Soils of Abandoned Mine Site in Dorowa, Northcentral Nigeria
}

\author{
Kehinde D. Oyeyemi, Joyce Abuka-Joshua, Ahzegbobor P. Aizebeokhai, \\ Osagie A. Ekhaguere, Opeyemi Joshua, and David O. Nduka
}

\begin{abstract}
Detailed geological mapping, petrographic description, and geochemical analysis were carried out to delineate variations in the rock types and their relationship with soil compositions in Dorowa, Barkin Ladi Local Government Area of Plateau State, Nigeria. The common rock types include hornblende-biotite-granite, biotite granite (medium to fine-grained), and pyroxene granite. The essential minerals identified by petrographic studies are quartz, plagioclase, biotite, hornblende, and pyroxene while zircon, magnetite, and ilmenite form part of the accessory minerals. The relative concentrations of heavy metals analyzed in the soils are in the order Fe $>$ $\mathrm{Cr}>\mathrm{Ni}>\mathrm{Pb}>\mathrm{Cu}>\mathrm{Zn}>\mathrm{Br}$. The results show that soils near mineralized areas have anomalous concentrations of heavy metals. The implication of this is the increase of bio-availability and toxicity, which may lead to serious health and environmental consequences.
\end{abstract}

Keywords Geology $\cdot$ Field mapping $\cdot$ Heavy metals $\cdot$ Abandoned mine site $\cdot$ Dorowa

\section{Introduction}

The evaluation of total metal concentrations in soils is useful for determining the vertical and horizontal extents of contamination and for estimating the increase in the net change in leaching to groundwater and surface run offs due to soil metal concentration over a given period. Though sediments and soils are said to form

K. D. Oyeyemi $(\varangle) \cdot$ J. Abuka-Joshua · A. P. Aizebeokhai Applied Geophysics Unit, Covenant University, Ota, Nigeria e-mail: kehinde.oyeyemi@covenantuniversity.edu.ng; kdoyeyemi@yahoo.com

\section{O. A. Ekhaguere}

Department of Physics, Federal University of Agriculture, Abeokuta, Nigeria

O. Joshua $\cdot$ D. O. Nduka

Department of Building Technology, Covenant University, Ota, Nigeria

(C) The Editor(s) (if applicable) and The Author(s), under exclusive license 
the ultimate sinks for heavy metals in the environment, changing environmental conditions may lead to remobilization and the release of metal pollutants into the water column and consequently into tropic levels of food chain. Dorowa is located in Barkin Ladi Local Government Area (LGA) and situated largely on the western side of the major road crossing Barkin Ladi village to Mangu. It is situated in plain lands and the area exhibits a nucleated settlement pattern that is linked to other smaller villages such as Babuje and Shurum. Cultivation of root crops, fruit trees, vegetables, grains, and cereals by irrigational methods in the dry season are the major preoccupation of the residents. There is no potable drinking water and water supply is mainly from hand-dug wells and numerous mine ponds found in the area. Soil type is mainly lateritic, ranging from reddish-brown to yellowish-brown. Some areas are clayey/silty-clay and rich alluvial soils exist along the stream channels and bank of the mine ponds, which encourages extensive agricultural activities in the area.

The study area is part of Plateau state, Nigeria that is widely recognized for its extensive mining activities. Open-cast mining and ore processing of minerals such as kaolin and tin is also carried out extensively in the area with about four processing mills. These unsafe and largely unlicensed mining activities undertaken by the local miners and the subsequent environmental pollution problems caused by the open pits, mine dumps and tailings is continually aggravated. Human influence on mining and disposal of waste effluents including heavy metals could result in reduced soil quality ultimately creating significant environmental pollution for both mankind and biodiversity [1-5]. The aim of this work was to conduct geological field mapping of the area and assess the heavy metals concentrations in the soils of abandoned mining sites in the study area.

\section{Materials and Methods}

Reconnaissance survey using Naraguta Sheet 168 NE was performed around Barkin Ladi with detailed geologic mapping within the study area. At specific locations, changes in lithology (and soil type), vegetation, and topography were observed. The entire geologic field mapping exercise and rock samples petrographic studies along with the soil sample geochemical analyses lasted for a period of five (5) months from October to March. A hand auger was used to scoop out the surface soil to a depth of about $10 \mathrm{~cm}$ in order to obtain five fresh samples at each location point and stored in sample bags and kept dry to avoid effects of moisture and bacterial action, which may alter the final results. Each sample was labeled clearly with its exact location. The presence of heavy metals was detected using the X-Ray Fluorescence and Atomic Absorption Spectrophotometer (AAS) methods. The sample analysis involved detailed examination of the samples to detect the presence of heavy metals such as $\mathrm{Zn}, \mathrm{Cu}, \mathrm{V}, \mathrm{Cr}, \mathrm{Ni}, \mathrm{Pb}$, and $\mathrm{As}$. 


\section{Results and Discussion}

The identified rock types within the area include hornblende-biotite-granite, biotite granite (medium to fine-grained) and pyroxene granite (Fig. 1). The essential minerals identified by petrographic studies for each mappable rock type are quartz, plagioclase, biotite, hornblende, and pyroxene while zircon, magnetite and ilmenite form part of the accessory minerals. From the data analysis (Table 1), most of the samples show anomalous concentrations of the metals except for $\mathrm{Zn}$, which is below its normal background value (Fig. 2). Hence, they are significantly linked to mineralization. All the samples, except SS-2 and SS-10 are seen to have the lowest anomalous concentrations of the heavy metals indicating that they were taken from either a barren zone or a slightly mineralized zone. Sample SS-7 has the highest anomalous concentrations (Table 1), which may indicate a strong presence of mineralization in

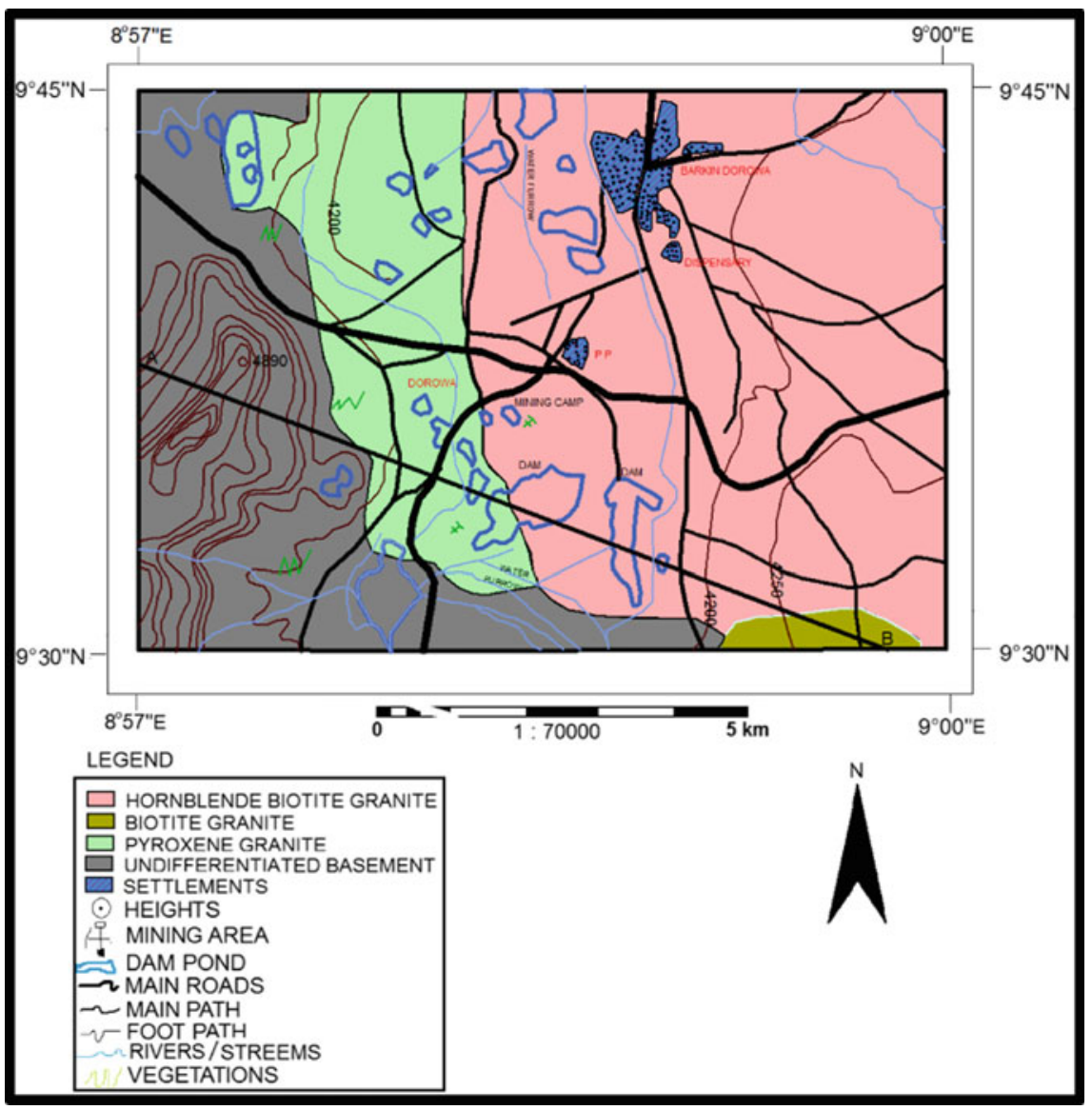

Fig. 1 The geological map of the Dorowa and its surroundings (Naraguta sheet $168 \mathrm{NE}$ ) 
Table 1 Concentrations of heavy metals in soils of abandoned mine site (ppm)

\begin{tabular}{l|l|l|l|l|l|l|l}
\hline Sample code & Zinc & Copper & Vanadium & Chromium & Nickel & Lead & Arsenic \\
\hline SS-1 & 67.1 & 77.6 & 966 & 628 & 140 & 70.6 & 41.5 \\
\hline SS-2 & 51.3 & 70 & 876 & 609 & 125 & 55.1 & 38.6 \\
\hline SS-3 & 95.4 & 108 & 875 & 522 & 177 & 77.7 & 54.6 \\
\hline SS-4 & 81.8 & 113 & 853 & 585 & 180 & 68 & 47.6 \\
\hline SS-5 & 53.7 & 76.7 & 1060 & 596 & 109 & 75.8 & 52.6 \\
\hline SS-6 & 93.4 & 182 & 881 & 710 & 246 & 91.1 & 63.1 \\
\hline SS-7 & 170 & 279 & 1400 & 925 & 268 & 267 & 188 \\
\hline SS-8 & 86.7 & 86.6 & 777 & 461 & 135 & 78.4 & 54.3 \\
\hline SS-9 & 54.1 & 71.8 & 908 & 558 & 105 & 68.4 & 47.1 \\
\hline SS-10 & 64.3 & 91.6 & 856 & 655 & 104 & 55.4 & 38.6 \\
\hline Permissible limit [6] & 300 & 140 & & & 100 & 300 &
\end{tabular}

2000

1500

1000

500

0
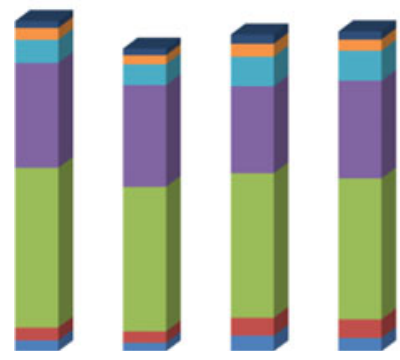

SS-1
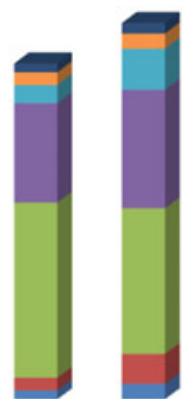

SS-5 SS-6
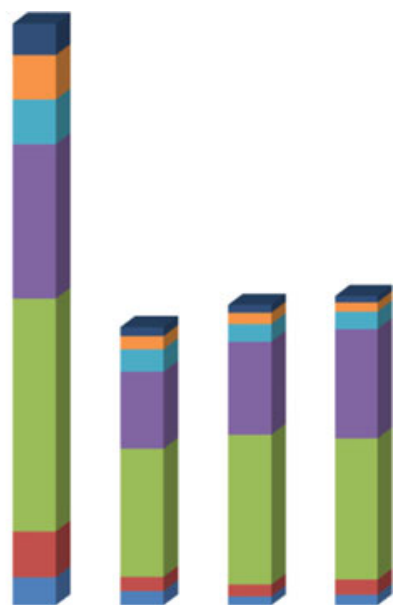

Zinc

Fig. 2 Concentrations of heavy metals in soil samples SS1-SS10 in parts per million (ppm)

the area. Among all the metals, vanadium shows a surprisingly high concentration in all the samples, which cannot be adequately explained, bearing in mind the rock types in the study area. But for $\mathrm{Cu}$, only that of SS-7 and SS-9 can be termed anomalous at $182 \mathrm{ppm}$ and $279 \mathrm{ppm}$, respectively.

Average values of Cr range between 522 and 700 ppm but that of SS-9 is anomalously high (at $925 \mathrm{ppm}$ ) which indicates that chromite ores may be present in the area and have probably undergone weathering to release the element in the area. As 
for Ni, only SS-7 and SS-9 have unusually high concentrations while the others have values within the same range, which is below crustal abundance of $200 \mathrm{ppm}$. The mode of occurrence of $\mathrm{Pb}$ is similar to that of $\mathrm{Zn}$ and both of/them exhibit the same pattern of dispersion. $\mathrm{Pb}$ concentrations in all the samples are anomalous based on its crustal abundance of $20 \mathrm{ppm}$. This could be due to $\mathrm{Pb}$ substitution in the K-feldspars, micas and calc-silicates present in the lithology of the area.

Transportation of these heavy metals is only by physical erosion of the soil itself and not by leaching because they are relatively insoluble. This insolubility is beneficial preventing them from precipitating into the water systems in solution. But their persistence in the soil profile means that once contaminated, the soil is likely to remain that way. Some metals are required as plant nutrients in minimal concentrations like, $\mathrm{Cu}$ and $\mathrm{Zn}$. But others like $\mathrm{Ni}, \mathrm{Pb}$, and $\mathrm{Cr}$ are not essential and are termed pollutants in whatever concentration they occur. Hence, soils of abandoned mine sites and mine tailings are potentially hazardous but may be remediated by the addition of lime to increase alkalinity and thereby reduce the levels of heavy metals. Acute contamination of the soil profile by heavy metals serves as a limitation to land use possibilities such as agriculture.

\section{Conclusion}

The anomalous concentrations of heavy metals found in the analyzed soil samples give evidence of extensive mineralized zones in the area. It therefore suggests that there is a high rate of contamination in the soil which can adversely affect the health of residents. The long-term effects may not be obvious but can accumulate over long periods of time to create hazards. There is need to carry out more research on the impact of these contaminants on the vegetables and other crops grown within the study area. The contribution of the soil contamination on both surface waters and groundwater in the area should also be investigated.

Acknowledgements The authors appreciate the Covenant University CUCRID for conference support.

\section{References}

1. Oyeyemi, K.D., Aizebeokhai, A.P., Oladunjoye, M.A.: Integrated Geophysical and Geochemical investigations of saline water intrusion in a coastal alluvial terrain, Southwestern Nigeria. Int. J. Appl. Env. Sci. 10(4), 1275-1288 (2015)

2. Oyeyemi, K.D., Aizebeokhai, A.P., Okagbue, H.I.: Geostatistical exploration of dataset assessing the heavy metal contamination in Ewekoro Limestone, Southwestern Nigeria. Data Brief 14, 110-117 (2017) 
3. Sanuade, O.A., Olaojo, A.A., Akanji, A.O., Omolaiye, G.E., Oyeyemi, K.D.: Assessment of metal pollution in surface soils and vegetable of Ifo village, Southwestern Nigeria. Indian J. Geosci. 71(3), 529-536 (2017)

4. Chibuike, G.U., Obiora, S.C.: heavy metal polluted soils: effect on plants and bioremediation methods. Appl. Environ. Soil Sci. 1(1), 1-12 (2014)

5. Das, S.K., Chakrapani, G.J.: Assessment of trace metal toxicity in soils of Raniganj Coalfied India.Environ. Monitor. Assess. 177(1-4), 63-71 (2011)

6. European Union. Heavy metals in wastes. European commission on environment (2002) 